\title{
Clinic morphological features of Goodpasture's syndrome manifested with respiratory disorders
}

\author{
Yu. M. Mostovoy ${ }^{1, A, E, F}$, A. V. Demchuk ${ }^{1, A-D}$, T. V. Konstantynovych ${ }^{1, A, B, C, E}$, \\ N. 0. Pentiuk ${ }^{1, A, C, D}$, L. V. Blazhevska $2, B, C$ \\ ${ }^{1}$ National Pirogov Memoril Medical University, Vinnytsia, Ukraine, ${ }^{2}$ Vinnytsia City Clinical Hospital № 1, Ukraine
}

A - концепція та дизайн АосліАження; B - збір даних; C - аналіз та інтерпретація даних; D - написання статті;

$\mathrm{E}$ - редагування статті; $\mathrm{F}$ - остаточне затвердження статті

Goodpasture's syndrome is one of rare pathological conditions. It stipulates problem of timely diagnostics and prescription of early pathogenic therapy for cessation of progressive autoimmune inflammation and safe of patient's life. Presented clinical case demonstrates difficulties of recognizing Goodpasture's syndrome in case of its debut with dominating symptoms and signs of bacterial affection of the lungs and severe respiratory failure.

Case presentation. We described case of Goodpasture's syndrome in the middle-aged woman (54 years old) which began from symptoms of community-acquired pneumonia, hemoptysis and finished tragically with developing severe respiratory and renal failures.

Conclusions. Management of community-acquired pneumonia patient, who has recurrent hemoptysis, minimal changes of the urinary system, who does not give adequate answer to the antibiotic treatment, must include additional investigation for revealing immunological systemic genesis of pulmonary tissue injury. It improves prognosis by virtue of early use adequate pathogenic therapy.

\section{КАініко-морфологічні особливості перебігу синдрому Гудпасчера, що маніфестував респіраторними розладами}

\section{Ю. М. Мостовой, А. В. Аемчук, Т. В. Константинович, Н. О. Пентюк, А. В. Блажевська}

Синдром Гудпасчера є одним із рідкісних патологічних станів, що зумовлює проблему його вчасної діагностики та призначення ранньої патогенетичної терапії, яка здатна зупинити прогресування автоімунного запалення та зберегти життя пацієнта. Наведений клінічний випадок демонструє складності розпізнавання синдрому Гудпасчера у разі його дебюту з домінуванням ознак бактеріального ураження легень і важкої легеневої недостатності.

Представлення випадку. Описали випадок синдрому Гудпасчера в жінки середнього віку (54 роки), який починався із симптомів негоспітальної пневмонії, кровохаркання та трагічно завершився розвитком важкої легеневої та ниркової недостатності.

Висновки. Курація пацієнта з негоспітальною пневмонією, який має рецидивуюче кровохаркання, мінімальні зміни сечовидільної системи та не дає адекватної відповіді на антибактеріальну терапію, має включати додаткові дослідження, що дадуть змогу виявити імунологічний системний генез ураження легеневої паренхіми. Це поліпшить прогноз завдяки ранньому призначенню адекватної патогенетичної терапії.

\section{Кминико-морфологические особенности течения синдрома Гудпасчера, манифестировавшего респираторными расстройствами}

\section{Ю. М. Мостовой, А. В. Аемчук, Т. В. Константинович, Н. А. Пентюк, А. В. Блажевская}

Синдром Гудпасчера - одно из редких патологических состояний, что обусловливает проблему его своевременной диагностики и назначения ранней патогенетической терапии, способной остановить прогрессирование аутоиммунного воспаления и сохранить жизнь пациента. Представленный клинический случай демонстрирует сложности распознавания синдрома Гудпасчера в случае его дебюта с преобладанием признаков бактериального поражения легких и тяжелой легочной недостаточности.

Представление случая. Описан случай синдрома Гудпасчера у женщины среднего возраста (54 года), который начинался симптомами внебольничной пневмонии, кровохарканьем и трагически завершился развитием тяжелой легочной и почечной недостаточности.

Выводы. Курация пациента с внебольничной пневмонией, который имеет рецидивирующее кровохарканье, минимальные изменения мочевыделительной системы и не дает адекватного ответа на антибактериальную терапию, должна включать дополнительные исследования, позволяющие установить иммунологический системный генез поражения легочной паренхимы. Это улучшит прогноз благодаря раннему назначению адекватной патогенетической терапии.
Key words:

Goodpasture's syndrome, respiratory failure, hemoptysis.

Pathologia 2018; 15 (3), 405-410 Dol: 10.14739/2310-1237. 2018.3.151882

E-mail: anna.demchuk@i.ua

Киючові слова: синаром Гудпасчера, мегенева недостатність, кровохаркання.

Патологія. - 2018. -

T. 15, № 3(44). -

C. $405-410$

Киючевые слова: синаром Гудпасчера, мегочная недостаточность, кровохарканье.

Патология. - 2018. T. 15, № 3(44). C. $405-410$ 
Diagnosis of autoimmune diseases of lung parenchyma remains one of the most difficult problems of modern pulmonology, due to their rare prevalence and the absence of specific clinical signs. One of these diseases that arises due to the production of antibodies to the basement membranes of the renal glomeruli and the pulmonary alveoli, is the Goodpasture's syndrome. It occurs in less than 1 case per million population per year [1] and usually develops in young people (20-30 years) or in elderly people (60-70 years), more often in men [2].

For the first time, this syndrome was described by Harvard pathologist E. Goodpasture during the management of a young man who had a bilateral infiltrative lung injury accompanied with hemoptysis and anemia after influenza. The patient died 6 weeks after the onset of the disease. Alveolar bleeding, diffuse necrosis of the alveoli and proliferative nephritis have been detected during the autopsy. Later, such cases were described by M. Stanton and J. Tange (1958). They proposed the term «Goodpasture's syndrome» [3]. In Ukraine, one of the brightest descriptions of the case of Goodpasture's syndrome was made by Y. M. Mostovoy et al. in 1984 [4].

Clinically Goodpasture's syndrome is manifested with symptoms of simultaneous lung and kidney damage (60-80\% of cases). Kidney damage preceded changes in the lungs in $20-40 \%$ of patients, and in less than $10 \%$ of cases, hemorrhagic vasculitis of the alveolar tissue is advanced, often without clinical signs of lesions of the glomerular apparatus $[2,5,6]$.

The causes of this syndrome are unknown. Its connection with smoking, virus infection (influenza A virus), use of cocaine, inhalation of metal dust, sepsis, treatment with monoclonal antibodies has been revealed [7]. A number of convincing data regarding the genetically determined nature of this disease have been obtained. Patients with HLA-DR15 and DR4 mutations have an increased risk of Goodpasture's syndrome compared to DR1 and DR7 carriers. A specific molecular analysis of the DRß chains revealed a special sequence of six amino acids common for DRw15 and DR4, which may increase the risk of developing Goodpasture's syndrome. The indicated sequence is absent in the carriers of HLA-DRB1 [8-10].

The basis of the pathogenesis of Goodpasture's syndrome is the formation of anti-glomerular basement membrane (GBM) antibody to the capillaries of the kidneys and alveoli. These antibodies belong to the IgG class, they are directed against the non-collagen (NC-1) domain of the alpha- 3 chain of the type IV collagen, which at the highest concentration is presented in the basement membranes of the pulmonary and renal capillaries [1]. Smoking, viral infections of the respiratory system, inhalation of hydrocarbanates activates the presentation of antigens of alveolar capillaries for circulating antibodies in people with hereditary predisposition. Circulating anti-GBM antibodies bind to basement membranes, fix the complement and cause the immune-inflammatory process in the renal glomeruli (glomerulonephritis) and alveoli (alveolitis). The main participating cells in immune inflammation are T-lymphocytes, monocytes, endothelial cells, polymorphonuclear leukocytes, and alveolar macrophages. Interaction between them is provided by molecular mediators, cytokines. Important role in the development of immune inflammation is played by metabolites of arachidonic acid, free oxygen radicals, proteolytic enzymes, adhesion molecules $[1,7,11,12]$.

The activation of alveolar macrophages, which produce about 40 cytokines, is extremely important in the development of alveolitis. Group I cytokines (chemotaxins, leukotrienes, interleukin-8) increase the migration of polymorphonuclear leukocytes in the lungs. Cytokines of II group (growth factors of platelet and macrophage) contribute to the transfer of fibroblasts in the lungs, which leads to the rapid development of proliferative-sclerotic processes. Alveolar macrophages also produce active forms of oxygen, proteases that destroy the tissue, causing alveolar hemorrhage $[1,7]$.

The immuno-inflammatory process has a rapid progressive development and often presented with a nonspecific clinical symptoms and signs. Considering the rareness of the Goodpasture's syndrome, it raises the problem of early diagnosis. The timely recognition of anti-GBM antibodiesdisease, when the function of the kidneys and lungs is still preserved, is the key to the effectiveness of modern pathogenetic treatment, which allows recovery in the vast majority of patients. Otherwise, the fulminant development of respiratory and renal failure leads to a lethal outcome $[7,11,12]$.

We present ourselves a clinical case of the Goodpasture's syndrome with dominating rapidly progressing respiratory symptoms, which made it difficult to diagnose.

\section{Case presentation}

Patient A., 54 years-old female, was admitted to the pulmonology department with complaints of cough with mucous-purulent sputum, hemoptysis, fever with body temperature up to $38.7^{\circ} \mathrm{C}$, shortness of breath during mild activity, decreased appetite, weight loss. The disease began acutely 18 days before hospitalization. Suddenly body temperature increased, dry cough arose. She received paracetamol for treatment. When hemoptysis appeared, the patient called "ambulance" and was taken to a hospital.

From the anamnesis it is known, the patient suffered from anemia during the last 17 years and its cause was not established. Treatment for anemia has not been received.

During an objective examination, the patient's condition was severe. Skin and mucous membranes were pale. Tachypnea was 32 per minute. Percussion determined the areas of small dull sound in the lower part of the both lungs. During auscultation rough vesicular breathing, fine moist rales were heard over the entire surface of the lungs. Pulse was 102 per minute, rhythmic, weak filling. Arterial pressure was $90 / 60 \mathrm{~mm} \mathrm{Hg}$. The heart sounds were rhythmic, weakened. Oxygen saturation was $90 \%$. Palpation of the stomach revealed painfulness in the right hypochondrium, the liver was $3 \mathrm{~cm}$ below the edge of the rib arc. The Pasternatsky's symptom was negative, peripheral edema was absent.

According to laboratory tests and instrumental investigations it was determined:

Anemia (hemoglobin $76 \mathrm{~g} / \mathrm{l}$, erythrocytes $2.1 \times 10^{12} / \mathrm{l}$, hematocrit $23 \%$ ).

Urinalysis revealed a small proteinuria (protein $0,066 \mathrm{~g} / \mathrm{l}$ ), erythrocytes $0-4$ in field of view, single hyaline cylinders. 

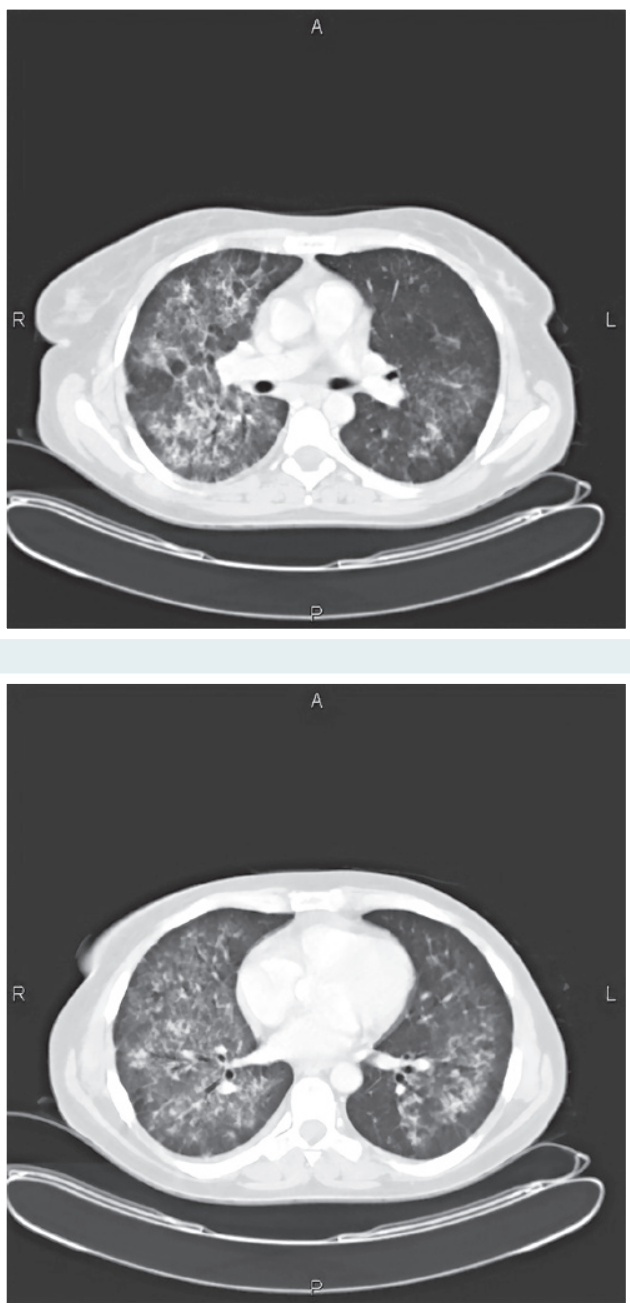

Chest X-ray: there were parenchymal nodules and consolidation, more pronounced in the basal segments. The right hilum was not differentiated due to infiltration. The left hilum was non-structural. Heart was not changed. Conclusion: bilateral polysegmental pneumonia.

Chest CT scan: Lymphadenopathy of the mediastinum (enlargement of intrathoracic lymph nodes up to $20 \times 11 \mathrm{~mm}$ ), diffused decrease in the pneumatization of both lungs due to multiple infiltration of round and irregular shape, up to $25 \mathrm{~mm}$ in size. Uneven thickening of the intercellular membranes and fibrous changes with the formation of hollow structures up to $15 \mathrm{~mm}$. Peripheral parts of the lungs were clear (Fig. 1).

In the sputum analysis - erythrocytes in large quantities, leukocytes 20-25 in the filed of view, cocci.

Biochemical tests did not reveal pathological changes. ECG data, echocardiography were within the norm. Ultrasound examination of the abdominal cavity revealed signs of chronic pyelonephritis, and renal calculi.

Based on the obtained data, the diagnosis was established: Community-acquired pneumonia of the upper, middle and lower lobes of the right lung, upper and lower lobes of the left lung, severe course, IV group.Respiratory failure of III degree. Hemoptysis.

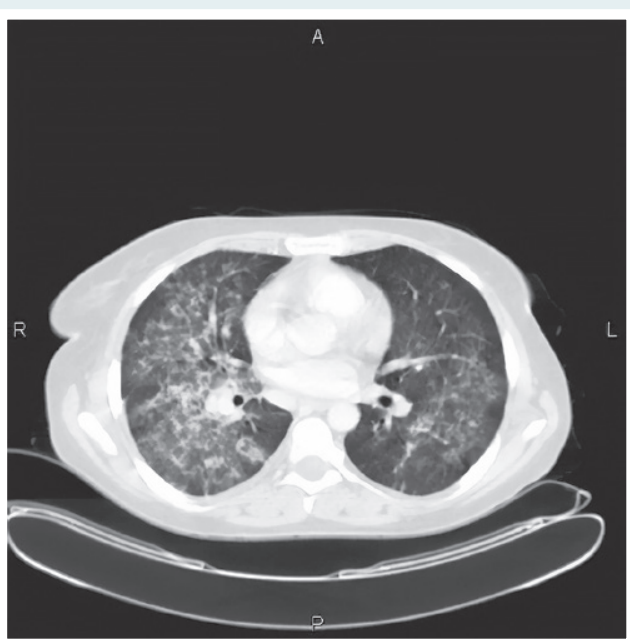

Fig. 1.

CT scan of the patient $A$. Multiple focal of infiltration of the pulmonary tissue of round and irregular shape, thickening of the interstitial membranes, fibrinous changes, hollow structures, lymphadenopathy of the mediastinum.
Taking into account severity of the patient's condition for the treatment of community-acquired pneumonia, she was given a combined antibiotic therapy: intravenous infusion of levofloxacin $500 \mathrm{mg}$ once daily, ceftriaxone/sulbactomix $1.0 \mathrm{~g}$ twice daily, amikacin $1.0 \mathrm{~g}$ once a day. For symptomatic treatment of hemoptysis hemostatic drugs were prescribed (aminocapronic acid $5 \%, 100 \mathrm{ml}$ intravenously once a day, dicinone $2 \mathrm{ml}$ intramuscularly once a day), for the correction of anemic syndrome - drugs that influence the synthesis of hemoglobin (vitamin B12 up to 500 units once a day intramuscularly, folic acid - 1 tablet, 3 times a day, inside), transfusion of erythrocyte mass (100 ml intravenously, once a week), oxygen therapy.

During a week, the patient's condition improved: body temperature was normalized, cough, shortness of breath, hemoptysis, sputum excretion decreased. According to the full blood test, anemia was stable. Control chest X-ray revealed a decrease in infiltrative changes of the lungs.

Taking into account the presence of hemoptysis in the patient and the peculiarities of lung infiltration during the hospital stay, a differential diagnostic search for a possible cause of hemoptysis was conducted.

To confirm or exclude lung cancer, tuberculosis, a cytological and bacteriological sputum examinations were performed. They did not detect malignant cells, mycobac- 

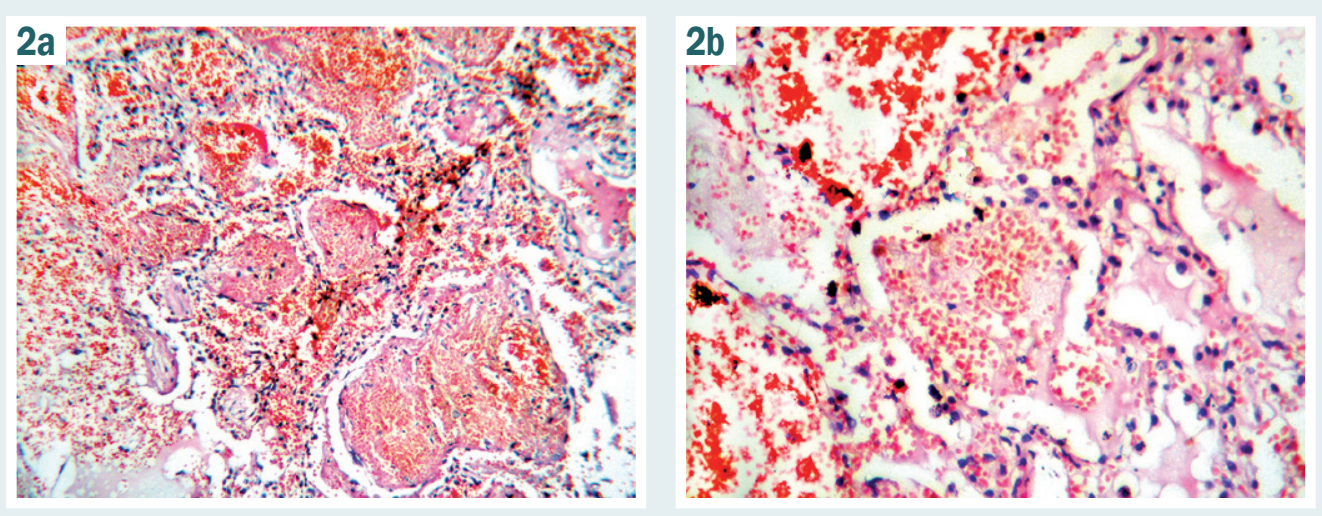

Fig. 2.

Photomicrograph of

histological preparations of

lungs patient $A$.

Hematoxylin and eosin. Magnification $\times 100$ (a) and $\times 200(b)$.
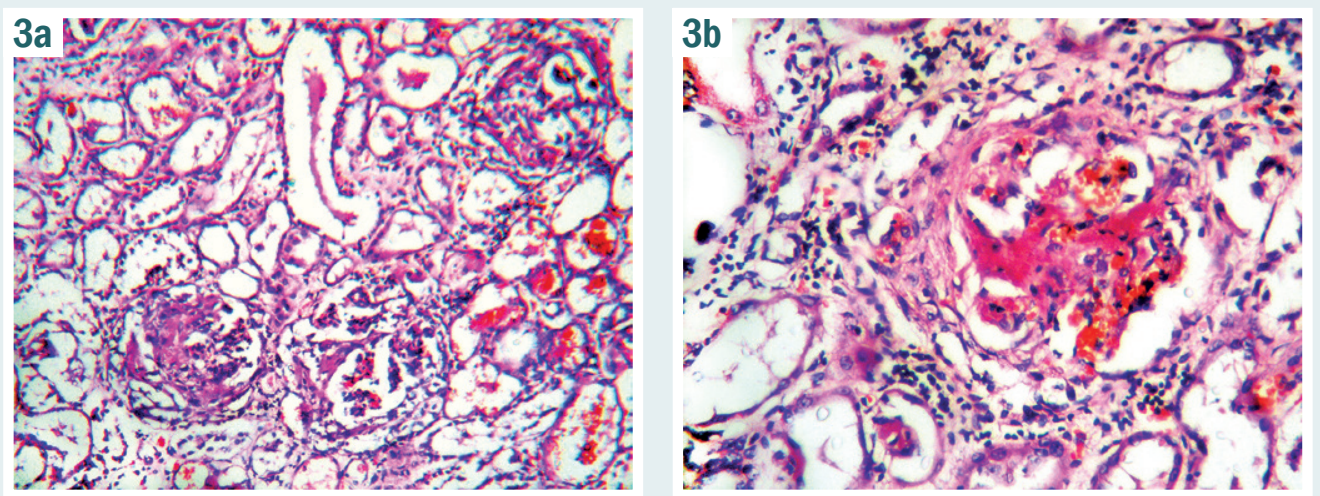

Fig. 3.

Photomicrograph

of histological preparations

of kidney patient $A$.

Hematoxylin and eosin.

Magnification $\times 100(a)$ and $\times 200$ (b).

terium tuberculosis and other morphological features of the tuberculosis process.

Biopsy of the pulmonary parenchyma would confirm bronchoalveolar cancer or interstitial lung disease (sarcoidosis, idiopathic pulmonary fibrosis), or rare lung syndromes (Goodpassture's syndrome, hemorrhagic vasculitis). The patient refused from transthoracic pulmonary biopsy.

However, two weeks after the onset of treatment, the patient's condition worsened again: body temperature increased to $38^{\circ} \mathrm{C}$, shortness of breath, weakness, cough increased. There was discomfort in the lumbar region. There was an episode of loss of consciousness, after which signs of respiratory failure increased - severe dyspnea, cyanosis, the oxygen saturation decreased to $77 \%$. In the full blood test signs of progression of anemia were found. In the urinalysis - macrohematuria (50-60 red blood cells in the field of view), leukocyturia, proteinuria of $0.15 \mathrm{~g} / \mathrm{l}$, which was evaluated as signs of chronic pyelonephritis exacerbation. According to ultrasound examination of the abdominal cavity, signs of splenomegaly, echocardiography - exudative pericarditis have been revealed.

It was assumed that a possible deterioration in the patient's condition was associated with the ineffectiveness of antibiotic therapy because the disease was caused either by resistant pathogens or non-bacterial infection. As a result, the antibacterial treatment of the patient was replaced. She was prescribed meropenem intravenously 1.0 g every 8 hours, linzolid $600 \mathrm{mg}$ twice daily, fluconazole $150 \mathrm{mg}$ once daily, monoxifloxacin $400 \mathrm{mg}$ once daily.

Progression of anemia, an episode of loss of consciousness, accompanied by a deterioration of respiratory failure, gave reason to think about a possible occult pulmonary haemorrhage. Signs of the progressive inflammatory process against the background of antibiotic therapy have made it possible to assume the immunological or neoplastic pathogenesis of the disease.

Considering confirmation of these pathological changes in the pulmonary tissue can only be obtained by morphological study the patient was offered a transthoracic lung biopsy, but she refused the procedure.

On the other hand, an immunological study was performed to detect lung injury as a component of systemic connective tissue disease (vasculitis, systemic lupus erythematosus, Goodpasture's syndrome, etc.). It revealed an increase in IgG anti-GBM-antibodies (7.7 times) which was the confirmation of a rare systemic disease with combined lung and kidney damage - Goodpasture's syndrome or anti-GBM-antibodies disease.

The current treatment of this syndrome includes the immunosuppressive therapy using pulse therapy with systemic corticosteroids and cyclophosphamide in combination with plasmapheresis [10-12].

After diagnosis conformation, the patient received methylprednisolone in pulse therapy. Due to progression of respiratory failure, she was given artificial ventilation of the lungs with the help of the "Fabius" apparatus in the BiPAP mode. For the correction of anemic syndrome, an erythrocyte mass $(100 \mathrm{ml})$ was re-administered. Parenteral nutrition was carried out using glucose and amino acids.

In spite of the treatment the patient's condition progressively deteriorated: signs of kidney damage increased - hematuria, proteinuria, cylindrury, renal failure. Despite the adequate artificial ventilation of the lungs, 
the respiratory failure progressed and acute heart failure arose. The patient died on the $23^{\text {rd }}$ day of hospitalization.

According to the results of the autopsy, the diagnosis of Goodpasture's syndrome was confirmed. Morphological signs of edema, hemorrhagic pulmonary syndrome and diffuse proliferative-productive glomerulonephritis were revealed (Fig. 2, 3).

In the lungs, alveolitis with a massive hemorrhagic exsudate, eosinophilic deposits, the formation of hyaline membranes in the lumen of the alveoli, and hemosiderosis were observed. In the interstitial membranes there were signs of capillaritis with the phenomena of proliferation, hyalinosis, pneumofibrosis (Fig. 2).

In the kidney examination, extracapillar, focal, segmental, and necrotizing glomerulonephritis were determined with eosinophilic deposits on the basement membranes of the Shumlyansky-Bowman capsule, in places with total sclerosis of the glomeruli (Fig. 3).

The cause of the patient's death was progressive respiratory failure.

\section{Discussion}

The presented clinical case of Goodpasture's syndrome in a middle-aged female demonstrates the complexity of diagnosing rare systemic diseases affecting the alveolar parenchyma. During hospitalization of the patient signs of bacterial infection and respiratory failure were dominated on the background of chronic anemia of unknown origin.

The infiltrative changes in the lungs were interpreted as signs of severe community-acquired pneumonia and the patient received appropriate treatment. The absence of convincing signs of kidney damage in the present case caused the delay in diagnosing this syndrome.

During the stay in a hospital, the patient's condition was changed wavelikely. After a primary antibiotic therapy, a short-term improvement was noted. However, subsequently, signs of respiratory failure increased again, hyperthermia persisted, pulmonary bleeding developed, anemic syndrome, renal insufficiency increased. The immunological examination with the detection of high lgG titers of the anti-GBM-antibodies was decisive test for the correct diagnosis - the Goodpasture's syndrome. Despite the prescribed pathogenetic treatment, it was not possible to stop the development of the fatal outcome.

According to the data of different studies, the use of pathogenetic treatment in the absence of signs of respiratory and renal failure leads to the survival of $86.9 \%$ of patients within one year; otherwise, the vast majority of patients die within several weeks or months after diagnosis $[12,13]$. Patient survival rates improved significantly after 2007, which are associated with the timely use of immunosuppressive therapy and plasmapheresis, however, dependence on hemodialysis, a decrease in the number of normal functioning nephrons and widened infiltrating changes in interstitial tissue considerably worsen the prognosis of patients [14]. There are few references to the effective use of rituximab, which is able to radically affect the key mechanisms of immunopathogenesis - to remove activated B-cells that produce anti-GBM-antibodies. The drug contributed to the positive change of the course of the disease, which was compli- cated by severe respiratory and renal failure, resulting in a complete reversion of lung injury, saving the patient's life, but the function of the kidneys did not resume [15].

\section{Conclusions}

Management of the patient with acute onset of disease, recurrent hemoptysis, minimal urinary tract changes, progressive respiratory failure, and fever, who does not provide an adequate response to antibiotic therapy, should include additional investigations and tests to detect the immunological systemic genesis of lung parenchyma injury. This will positively affects the outcome due to the early prescibtion of adequate pathogenetic therapy.

Conflicts of interest: authors have no conflict of interest to declare. Конфмікт інтересів: віАсутній.

Information about authors:

Mostovoy Yu. M., MD, PhD, DSc, Professor, Head

of the Department of Propedeutics of Internal Medicine, National Pirogov Memorial Medical University, Vinnytsia, Ukraine.

Demchuk A. V., MD, PhD, DSc, Associate Professor, Professor

of the Department of Propedeutics of Internal Medicine, National Pirogov Memorial Medical University, Vinnytsia, Ukraine. Konstantynovych T. V., MD, PhD, DSc, Professor of the Department of Propedeutics of Internal Medicine, National Pirogov Memorial Medical University, Vinnytsia, Ukraine. Pentiuk N. O., MD, PhD, DSc, Associate Professor, Professor of the Department of Propedeutics of Internal Medicine, National Pirogov Memorial Medical University, Vinnytsia, Ukraine.

Blazhevska L. V., Head of Pulmonology Department, Vinnytsia City Clinical Hospital \#1, Ukraine.

\section{Відомості про авторів:}

Мостовой Ю. М., А-р меА. наук, професор,

зав. каф. пропеАевтики внутрішньої медицини, Вінницький національний медичний університет імені М. І. Пирогова, Україна.

Аемчук А. В., А-р меА. наук, Аоцент, професор

каф. пропеАевтики внутрішньої меАицини, Вінницький національний медичний університет імені М. І. Пирогова,

Україна.

Константинович Т. В., А-р меА. наук, професор

каф. пропедевтики внутрішньої меАицини, Вінницький національний медичний університет імені М. І. Пирогова, Україна.

Пентюк Н. О., А-р меА. наук, Аоцент, професор каф. пропедевтики внутрішньої меАицини, Вінницький національний медичний університет імені М. І. Пирогова, україна.

Блажевська ^. В., зав. пульмонологічного відаілення, КНП “Вінницька міська клінічна мікарня № 1", Україна.

\section{Сведения об авторах:}

Мостовой Ю. М., А-р меА. наук, профессор,

зав. каф. пропеАевтики внутренней меАицины, Винницкий национальный меАицинский университет имени

Н. И. Пирогова, Украина.

Аемчук А. В., А-р меА. наук, Аоцент, профессор каф. пропедевтики внутренней меАицины, Винницкий национальный медицинский университет имени Н. И. Пирогова, Украина.

Константинович Т. В., А-р меА. наук, профессор каф. пропедевтики внутренней медицины, Винницкий национальный медицинский университет имени Н. И. Пирогова, Украина.

Пентюк Н. А., А-р меА. наук, Аоцент, профессор каф. пропеАевтики внутренней меАицины, Винницкий национальный медицинский университет имени Н. И. Пирогова, Украина. 
Блажевская ^. В., зав. пульмонологическим отАелением, КНП "Винницкая городская клиническая больница № 1", Украина.

Надійшла Ао редакції / Received: 12.10.2018

Після Аоопрацювання / Revised: 24.10.2018

Прийнято Ао Аруку / Accepted: 05.11.2018

References

[1] Lahmer, T., \& Heemann, U. (2012)Anti-glomerular basement membrane antibody disease: a rare autoimmune disorder affecting the kidney and the lung. Autoimmun Rev, 12(2), 169-173. doi: 10.1016/j.autrev.2012.04.002

[2] Kathuria, P., Sanghera, P., Stevenson F. T., \& Sharma S. (2017) Goodpasture Syndrome. Medscape Reference: WebMD. Retrieved from https://emedicine.medscape.com/article/240556-overview.

[3] Stanton, M. C., \& Tange, J. D. (1958) Goodpasture's syndrome (pulmonary haemorrhage associated with glomerulonephritis). Australas Ann Med, 7(2), 132-144.

[4] Mostovoj, Y. M., \& Demchuk, A. V. (2008) Sindrom Gudpaschera [Goodpasture Syndrome]. Zdorovia Ukrainy, 3/1, 56-57. Retrieved from http:// health-ua.com/article/16926-sindrom-gudpaschera. [in Russian].

[5] Pedchenko, V., Bondar, O., Fogo, A. B., Vanacore, R., Voziyan, P. Kitching, A. R., et al. (2010) Molecular architecture of the Goodpasture autoantigen in anti-GBM nephritis. N Engl J Med, 363(4), 343-354. doi: 10.1056/NEJMoa0910500.

[6] Scollo, V., Zanoli, L., Russo, E., Distefano, G., \& Rapisarda, F. A (2017) Case of Rare Diffuse Alveolar Hemorrhage and Review of Literature Clin Med Insights Case Rep, 10, 1179547617726077. doi: 10.1177/1179547617726077.

[7] Yang, R., Cui, Z., Zhao, J., \& Zhao, M. H. (2009) The role of HLA-DRB1 alleles on susceptibility of Chinese patients with anti-GBM disease. Clin Immunol, 133(2), 245-250. doi: 10.1016/j.clim.2009.07.005.

[8] Kitagawa, W., Imai, H., Komatsuda, A., Maki, N., Wakui, H., Hiki, Y., \& Sugiyama, S. (2008) The HLA-DRB1*1501 allele is prevalent among Japanese patients with anti-glomerular basement membrane antibody-mediated disease. Nephrol Dial Transplant, 23(10), 3126-3129. doi: 10.1093/ndt/gfn179.

[9] Fisher, M., Pusey, C. D., Vaughan, R. W., \& Rees, A. J. (1997) Susceptibility to anti-glomerular basement membrane disease is strongly associated with HLA-DRB1 genes. Kidney Int, 51(1), 222-229. doi: https:// doi.org/10.1038/ki.1997.27.

[10] Dammacco, F., Battaglia, S., Gesualdo, L., \& Rakanelli, V. (2013) Goodpasture's disease: a report of ten cases and a review of the literature. Autoimmune Rev, 12(11), 1101-1108. doi: 10.1016/j. autorev.2013.06.014

[11] Greco, A., Rizzo, M. I., De Virgiio, A., Gallo, A., Fusconi, M., Pagliuca, G., et al. (2015) Goodpasture's syndrome: a clinical update. Autoimmune Rev, 14(3), 246-253. doi: 10.1016/j.autrev.2014.11.006.

[12] Stojkovikj, J., Zejnel, S., Gerasimovska, B., Gerasimovska, V., Stojkovic, D., Trajkovski, M., et al. (2016) Goodpasture syndrome diagnosed one year and a half after the appearance of the first symptoms (case report). Open Access Maced J Med Sci, 4(4), 683-687. doi: 10.3889/ oamjms.2016.127.

[13] Huart, A., Josse, A. G., Chauveau, D., Korach, J. M., Heshmati, F., Bauvin, E., et al. (2016) Outcomes of patients with Goodpasture syndrome: a nationwide cohort-based study from the French Society of Hemapheresis. J. Autoimmun., 73, 24-29. doi: 10.1016/j.jaut.2016.05.015.

[14] Van Daalen, E. E., Jennette, J. C., McAdoo, S. P., Pusey, C. D. Alba, M. A., Poulton, C. J., et al. (2018) Predicting outcome in patients with anti-GBM glomerulonephritis. Clin J Am Soc Nephrol, 13(1), 63-72. doi: $10.2215 / C J N .04290417$.

[15] laremenko, O. B., Golovach, I. Yu., Stelmashchuk, V. P., Myasnyi, I. S., Mikhalchenko, E. M., Matijko, V. N., \& Petrenko, L. V. (2018) Blagopriyatnyj iskhod gemorragicheskogo al'veolita, obuslovlennogo bolezn'yu antitel k bazal'noj membrane pochechnykh klubochkov, pri lechenii rituksimabom [A favorable outcome of hemorrhagic alveolitis caused by antibodies to glomerular basement membrane, in the treatment with rituximab]. Ukrainskyi pulmonolohichnyi zhyrnal, 2, 39-46. [in Russian]. doi: 10.31215/2306-4927-2018-100-2-39-46. 